\title{
Housing Demand, Regional House Prices and Consumption
}

\author{
By \\ Carl J. Liebersohn \\ B.A., Mathematics and Economics \\ Amherst College, 2009
}
SUBMITTED TO THE SLOAN SCHOOL OF MANAGEMENT IN PARTIAL
FULFILLMENT OF THE REQUIREMENTS FOR THE DEGREE OF
MASTER OF SCIENCE IN MANAGEMENT SCIENCE RESEARCH
at the

MASSACHUSETTS INSTITUTE OF TECHNOLOGY

JUNE 2018

(C2018 Massachusetts Institute of Technology. All Rights Reserved.

Signature of Author:

\section{Signature redacted}

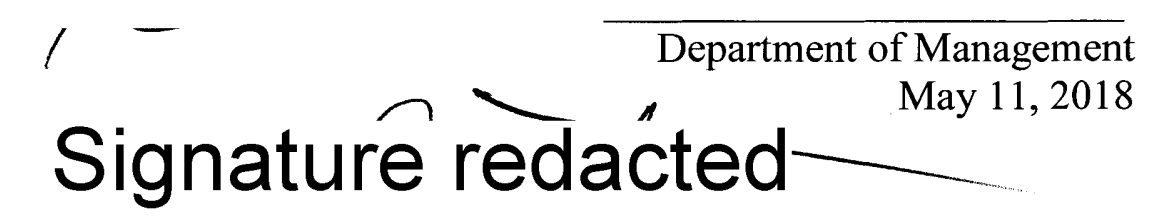

Certified by:

Accepted by:

Catherine Tucker Sloan Distinguished Professor of Management Professor of Marketing MASSACHUSEIS INSTITUTE
OF TECHNOLOGY
JUN 152018
LIBRARIES Chair, MIT Sloan PhD Program ARCHIVES 


\section{$\widetilde{\text { MITLibraries }}$}

77 Massachusetts Avenue

\section{DISCLAIMER NOTICE}

Due to the condition of the original material, there are unavoidable flaws in this reproduction. We have made every effort possible to provide you with the best copy available.

Thank you.

The images contained in this document are of the best quality available. 


\title{
Housing Demand, Regional House Prices and Consumption
}

By

\author{
Carl J. Liebersohn
}

Submitted to the Sloan School of Management on May 11, 2018 in Partial Fulfillment of the Requirements for the Degree of Master of Science in Management Science Research

\begin{abstract}
This paper provides a new explanation for regional variation in the 2000-2012 housing and consumption boom and bust. Cities with a greater share of growing industries experienced larger housing demand shocks, larger house price increases from 2001-2006 and greater price declines from 2006-2011. Consistent with theory, price effects were stronger in housingsupply inelastic cities. City-level differences in housing demand are also correlated with supply elasticity. Controlling for industry, I estimate a durables consumption-house price elasticity of 0.08 from $2001-2006,60 \%$ smaller than estimates without the controls. Post2006, the estimated elasticity is 0.19 and housing prices rather than local conditions explain consumption changes.
\end{abstract}

Thesis Supervisor: Jonathan A. Parker

Title: Robert C. Merton (1970) Professor of Finance 


\section{ACKNOWLEDGEMENTS}

Special thanks to my committee members, Antoinette Schoar, Jonathan Parker and Jim Poterba. Thanks also to Xavier Giroud, David Autor, David Berger, Nittai Bergman, Stijn Claessens, Ricardo Correa, Leonid Kogan, Emi Nakamura, Albert Saiz, Raven Saks, Amir Sufi, Bill Wheaton, Asaf Bernstein, Kirill Borusyak, Daniel Green, Greg Howard, Peter Hull, Stephanie Lo, Rachael Meager, and Tejaswi Velayudhan for helpful comments and conversations. Thanks to the participants of the MIT finance, public finance, macro and fourth-year lunches, to participants at the Macro Financial Modeling Group Winter 2016 meeting, and to the members of the Federal Reserve Board International Finance Seminar for helpful comments. It was supported by the Macro Financial Modeling Group Dissertation Fellowship. This work was completed in part while the author was a Dissertation Fellow at the Federal Reserve Board; the views contained herein are those of the author and do not necessarily reflect those of the Board of Governors of the Federal Reserve System, its members, or its staff. I am solely responsible for any errors. 


\section{Introduction}

The close relationship between housing prices, business cycles, and consumption is extremely well documented (Mian and Sufi, 2014a; Mian et al., 2013; Leamer, 2007; Guren et al., 2017). This correlation was particularly salient during the Great Recession, which followed a crash in the housing market. The size of the housing boom and bust preceding the Great Recession varied across the United States and cities with the most volatile housing prices had the most volatile consumption as well. Several papers have used crosssectional variation in house price changes to quantify and explain the effect of housing prices on consumption and other regional variables. While it is tempting to interpret the observed correlation between housing prices and consumption as causal, the factors driving the regional differences in the size of the boom and bust may also have had a direct effect on consumption, motivating the use of instrumental variables strategies that exploit plausibly exogenous variation in the size of the boom and bust (Mian and Sufi, 2014a; Mian et al., 2013). This paper reevaluates the reasons for heterogeneity in housing prices from 2001-2011. The regional variation in the housing boom can be attributed to both housing supply differences and to differences in demand which arise from differential growth in local industries. This differential growth affected both local housing demand (which affected house prices) and household consumption.

The most widely-used empirical model of the housing market attributes regional differences in the size of the housing boom and bust primarily to differences in the elasticity of housing supply across regions. While elasticity alone partially explains the regional variation in housing price growth from 2001-2006, this model also gives rise to empirical puzzles. Regions with a less elastic housing supply did see greater price appreciation, but they also had more new construction, even though most housing market models predict that higher prices are due to less new construction. Moreover, housing supply elasticity explains only a small fraction of the variation in price appreciation in general and under- 
predicts the size of the price boom in the Southwest (Nathanson and Zwick, 2012). This paper shows that part of the reason for these puzzles is that demand shocks due to local industry exposure had important effects on housing price growth.

The United States experienced steady GDP growth in the early 2000s, but there was substantial variation in this growth across industries. Therefore, differential composition of industries translated into variation in income growth. Areas that were more exposed to declining industries, particularly manufacturing, experienced a much smaller housing boom and bust. Interacting exposure to growing industries with the measure of housing price elasticity developed by Saiz (2010), I show that housing prices rose most in areas where both local employment was in growing industries and housing was inelastically supplied. As a simple proxy for exposure to slower-growing industries, I consider the fraction of employment in manufacturing in 1998. Using manufacturing employment share as a proxy for regional housing demand yields estimates which are consistent with a simple theoretical framework.

Furthermore, industry exposure is highly correlated with housing supply elasticity, implying that estimates which do not control for heterogeneous demand they may suffer from omitted variables bias. Accounting for local industry exposure partially resolves the housing market puzzles. Areas with larger housing demand shocks had more construction from 2001-2011 and, when controlling for these shocks, housing supply elasticity no longer has a statistically significant negative effect on new construction. Moreover, the addition of industry controls reduces the unexplained "excess" price growth in Southwestern cities by $0.09 \log$ points - from 0.26 to 0.17 - from 2001-2006 in preferred specifications (although it does little to explain the relatively larger bust in these areas). Including industry exposure also improves the $R^{2}$ of regression specifications used to explain prices appreciation from 2001-2006.

A flourishing body of empirical literature uses variation in housing prices over this period to study how housing prices affect household consumption (Mian et al., 2013; 
Dynan, 2012; Kaplan et al., 2016). Because regional demand shocks played an important role in the size of the housing boom and bust, I show that much of the correlation between housing prices and consumption from 2001-2006 was due to the effects of income growth on both housing demand and consumption rather than the direct effect of housing prices on consumption.

I estimate the effect of housing prices on consumption by instrumenting for housing prices using housing supply elasticity, the method pioneered by Mian and Suf (2011). I augment this instrument by controlling for local industry composition. Accounting for local industry exposure, I find that the estimated effect of housing prices on both durables and non-durables consumption expenditures from 2001-2006 is reduced by about $65 \%$ compared to models which do not include these variables. In several specifications I cannot statistically reject that the consumption-house price elasticity is zero after adding industry controls. This is because regions with an elastic housing supply also had more manufacturing, which both led to relatively lower prices and relatively lower demand for consumption. Estimates that do not control for manufacturing exposure may conflate these two effects.

On the other hand, the estimated consumption-housing price elasticity for the 20062011 period is large and statistically distinguishable from zero, even after accounting for industry exposure. The addition of industry controls either has no effect on or increases the estimated consumption-house price elasticity. The reason for the difference between 2001-2006 and 2006-2011 estimates is that the sign of the omitted variable bias is positive from 2001-2006 but negative from 2006-2011. The direct effect of manufacturing exposure on consumption was negative from 2006-2011, as it was from 2001-2006. At the same time, the effect of elasticity on housing prices was positive because more elastic areas had smaller housing busts. Since manufacturing-heavy regions also had an elastic housing supply, these two effects partially cancel each other out in estimates which do not account for the correlation between housing supply elasticity and manufacturing. Putting together 
my results from both time periods, I show that the effect of housing prices on consumption was small from 2001-2006 but large from 2006-2011 and that this difference is statistically significant.

A different consumption elasticity with respect to positive and negative house price shocks is consistent with several existing theories. In the model proposed by Berger et al. (2015), housing booms change the composition of home-owners by increasing the number of liquidity-constrained individuals who own homes. Because the typical homeowner is more liquidity constrained when housing prices start to fall than when they start to rise, falling prices cause greater changes to consumption than rising prices do. A second possible reason is that cashflow shocks, rather than changes to the value of home equity, are important for household default and consumption. The effect of cashflow shocks on consumption may have been greatest in areas with falling housing prices because homeowners' monthly mortgage payments were highest in these areas, as these were the areas with the largest housing booms.

\section{Data}

The bulk of the estimates are based on panels of state- and city-level statistics described in this section. Using this panel, I calculate five-year differences of many of the main variables that comprise the years 2001-2006 (what I call the housing boom) and 20062011 (the bust); results are similar using different years to denote the boom and bust. My main units of analysis are states and U.S. CBSA / Metropolitan Divisions based on 2013 definitions.

Data on housing prices is from the Federal Housing Finance Administration (FHFA). The main results of this paper are very similar using county-level housing price measures from Zillow. Both are aggregated to the CBSA / Metropolitan Division level.

Several empirical results investigate the effects of local shocks on housing demand. As 
a source of plausibly exogenous variation in local demand, I use two measures of local exposure to industries which expanded or contracted during the relevant time periods. The first is a measure of regions' ex ante exposure to industries with large ex post growth. Measures of this sort are commonly known as "Bartik shocks" (from Bartik, 1991) and are widely used in the empirical study of regional macro-economics. To create this measure, I predict income growth for city $i$ by interacting $i$ 's exposure to each industry $j$ with industry $j$ 's national payroll growth:

$$
\text { Bartik }_{i}=\sum \text { Exposure }_{i, j} \times \text { Growth }_{j}
$$

This measure is constructed using 2-digit NAICS industries. I fix the year of exposure to 1998 - prior to the start of the housing boom - and use growth over 1998-2006 to create the measure.

A second source of regional demand variation comes from exposure to the manufacturing sector. Manufacturing was the largest employer in 1998 (among 2-digit NAICS industries) and underwent a dramatic decline over the time that coincided with the housing boom. Much of the variation in the Bartik measure is due to variation in exposure to manufacturing. Moreover, the relationship between manufacturing exposure and housing prices is also of interest on its own. Regional labor force exposure data is provided by County Business Patterns (CBP). I use 1998 as a base year for regional industry exposures. Using 2001 as a base year yields very similar results. I focus on measuring labor force exposure at the 2-digit NAICS level to ensure that measurements are uniform even as NAICS definitions changed for more detailed categories.

Exposure to trade shocks provide an alternative source of exogenous demand. Using a measure from Acemoglu et al. (2014), I find similar but noisier results.

To quantify regional elasticity of housing supply, I use the measure created by Saiz (2010). This measure was downloaded from Albert Saiz's web site. Saiz (2010) provides se- 
veral version of the elasticity measure, including measures of legal barriers to construction, land unavailability, and population size, as well as a composite index that combines all three. Following the existing literature on consumption, I study both the overall elasticity measure and the land unavailability measure, which I convert to 1-unavailability so that a greater value for either measure corresponds to a more elastic area. Because the unavailable land measure is less likely to be time-variant than the composite elasticity measure, previous research has preferred this as an instrument for housing prices during the boom and bust, as its time invariance may make it less affected by the factors that directly affected housing prices. Therefore, most of the findings in this paper will use the land unavailability measure as well. ${ }^{1}$

County-level housing unit counts are taken from Intercensal Estimates. Housing construction is measured as the log change in total number of housing units, according to intercensal estimates from the U.S. Census Bureau. Calculating new construction as the number of permitted units (using HUD data) divided by existing units yields similar results. Cities with a decline in units of above 0.05 log points are not included.

As additional control variables, I measure regional demographic features using largely data collected from the 2000 Decennial Census. These demographic controls are per capita income, the fraction of households with a mortgage, median age, and the fraction of houses that are owner-occupied. I also measure the fraction of mortgages that were denied in each region in 1996, which Mian and Sufi (2009) argue is a measure of latent mortgage demand. Results are similar when using a variety of other control variables taken from the housing literature, such as those used in Albouy (2015).

Aggregate consumption data is from BEA regional accounts, which includes household consumption divided into several categories. I subtract housing and furniture from the overall measure and durables measure in order to study only non-housing consumption.

\footnotetext{
${ }^{1}$ Furthermore, Section 4 will present evidence that the composite elasticity measure is correlated with unmeasured demand to a greater degree than the unavailable land measure, thus validating this approach.
} 
Because regional accounts PCE data is only available at the state level, and not at the CBSA level, estimates using this data have states as their unit of analysis rather than CBSAs.

Few sources of CBSA-level consumption data have a long history available. In order to proxy for consumption at the CBSA level for the 2001-2006 period, I use retail employment measured in County Business Patterns, which Mian and Sufi (2014b) show is closely linked to consumption. Guren et al. (2017) argue that this is a good consumption proxy. For 2006-2011, I aggregate household-level data from Nielsen Homescan non-durables expenditure that is collected as part of a nationally representative survey of retail consumption expenditures.

Table 1 shows summary statistics of the main variables.

\section{Theoretrical Framework and Motivating Evidence}

The size of the housing boom varied greatly by city. Figure 1 shows the path of housing prices in the 20 largest U.S. cities beginning in 2000. Cities in the American Southwest and on the coasts, such as Boston, Las Vegas, San Francisco and New York, experienced the largest booms. But many cities - those at the bottom of the graph - barely had housing booms at all. These are mostly Midwestern and Southern cities. The line at the very bottom of the graph represents Dallas, which had the smallest housing boom among major U.S. cities.

In this section, I describe the benchmark framework that explains variation in housing prices accommodating both heterogeneous demand shocks and heterogeneous housing supply elasticities. I derive predictions of this model and relate these predictions to previous research on the housing market from 2001-2011. I then discuss how these predictions 
relate to estimates of the house-price consumption elasticity.

I begin with a model of the housing market similar to models in Saiz (2010), Glaeser et al. (2008) and Davidoff (2013). Suppose that housing is supplied in a spot market. Cities vary in their elasticity of housing supply $\beta_{i} .{ }^{2}$ The quantity of new housing supplied in city $i$ is $q_{i}^{s}$. This is increasing in housing price shocks $p_{i}$, which are mediated by housing supply elasticity. Supply and demand are:

$$
\begin{gathered}
\Delta \log \left(q_{i}^{s}\right)=\beta_{i} \Delta \log \left(p_{i}\right) . \\
\Delta \log \left(q_{i}^{d}\right)=-\Delta \log \left(p_{i}\right)+\Delta \log \left(y_{i}\right) .
\end{gathered}
$$

This yields

$$
\begin{aligned}
\Delta \log q_{i} & =\frac{\beta_{i}}{\beta_{i}+1} \Delta \log \left(y_{i}\right) \\
\Delta \log p_{i} & =\frac{1}{\beta_{i}+1} \Delta \log \left(y_{i}\right)
\end{aligned}
$$

A large body of recent literature implicitly adopts the assumption that the housing boom was caused by a national housing demand shock that was either uniform or independent of the supply elasticity. Under this assumption, it is possible to to study the effect of housing prices on various outcomes using the Saiz (2010) supply elasticity as an instrument for housing prices. Combining this assumption with Equations 4 and 3 yields several empirical predictions, some of which have been tested by the existing literature.

The first prediction is that more elastic regions should have smaller price increases. Previous papers, such as Glaeser et al. (2008), have found that this prediction does hold empirically. I confirm their findings in Table 2, which estimates an empirical analogue to

\footnotetext{
${ }^{2}$ I abstract from housing demand elasticity which in reality may also vary by city. Harmon (1988) reviews research on demand elasticity and estimates a long-run average demand elasticity of approximately 1 , justifying this assumption in my model. In my empirical estimates, I show my results are robust to the inclusion of control variables associated with demand elasticity.
} 
Equation 4 under the assumption that demand shocks are independent of housing supply elasticity:

$$
\Delta \log p_{i}=\text { Elasticity }_{i}+\varepsilon_{i}
$$

Using both measures of housing supply elasticity, I find that inelastic cities had larger booms and larger busts, and these relationships are statistically significant at the $1 \%$ level. However, the small $R^{2}$ of these specifications indicates that much of the variation in housing prices remains unexplained.

The second prediction is that elastic regions should have greater quantity growth than inelastic regions, at least from 2001-2006. ${ }^{3}$ Davidoff (2014) and Davidoff (2013) show that this does not hold over periods lasting several decades. I show this for the 20012006 period in Table 3, which again estimates Equation 5, but with quantities (number of housing units) as the dependent variable rather than prices. The overall rate of permitting in the more-inelastic and more-elastic half of the country is graphed in Figure 4. It is negative using both measures from 2001-2006, statistically significantly so for the overall elasticity measure. Given the large and positive price effects of housing supply using both measures, this is hard to make sense of these results in the uniform shock framework. Instead, it implies that city-level housing supply elasticities are likely correlated with local demand shocks. If areas with an inelastic housing supply had large demand shocks, then they would have had larger price increases but not necessarily smaller construction booms.

The estimated association between composite elasticity and new units, shown in Column 2 , is large enough to reject zero effect at the $1 \%$ level, whereas the association between available land and new units is negative but not so large as to reject zero effect even at the $10 \%$ level. This provides some support for the view that the available land measure is less endogenous than the composite elasticity measure in the sense that it is

\footnotetext{
${ }^{3}$ Glaeser et al. (2008) show that when prices are following a housing bubble, the theoretical association between prices and elasticity is of ambiguous sign.
} 
less correlated with unobserved demand shocks, making it more appropriate to use as an instrument for housing prices. By contrast, neither elasticity measure has an association with new construction that is statistically distinguishable from zero from 2006-2011.

Another possible concern with the assumption of independent demand shocks is that it gives rise to incorrect predictions about housing prices in specific regions of the United States. The housing boom was especially large in cities located in the Southwestern U.S. despite the fact that these cities had a high housing supply elasticity. Table 4 estimates Equation 5 adding an indicator for cities in Nevada, Arizona and New Mexico. In these cities, housing prices rose $0.26 \log$ points more than what one would expect from their elasticity alone during the boom and fell by $0.34 \mathrm{log}$ points more than one would expect during the bust.

These inconsistencies with the "uniform shock" model provide a motivation for incorporating city-specific demand shocks. From Equations 3 and 4, one can make three key predictions about housing demand shocks. First, anything that raises city payrolls can raise demand for housing in that city, and therefore lead to more construction and higher prices. Second, these effects are mediated by housing supply elasticity: The effect on prices should be greater in cities with an inelastic housing supply and the effect on quantities should be greater in cities with an elastic housing supply. Third, to explain why construction is unconditionally negatively correlated with housing supply elasticity, demand shocks should be greater in inelastic areas.

Local demand shocks also matter for estimates of the consumption-house price elasticity. If demand shocks are correlated with housing supply elasticity elasticity, then the latter may not be a valid instrument for housing prices, as Davidoff (2014) and Davidoff (2013) argue. The reason is that local economic conditions which affect housing demand may also directly affect the outcome variables in question. For example, if local income shocks are correlated with the housing price elasticity, then the negative correlation between consumption growth and house price growth may be due to income shocks rather 
than housing prices per se. Adding demand shocks as control variables may therefore provide new insight into the reasons for the correlation between housing prices and consumption.

The next section will show that exposure to growing industries, and specifically to the manufacturing sector, satisfies the predictions for local demand shocks and resolves the puzzles with the housing market model. It also changes the coefficient estimates for the housing-price consumption elasticity.

\section{Empirical Results}

The empirical results are divided into three parts. The first part presents estimates of the effects of industry exposure on housing prices. Compared to models built on the assumption of independent or uniform demand shocks, a model which explicitly accounts for

local demand explains more of the variation in housing prices from 2001-2006. Second, I revisit the puzzles discussed in the previous section. Accounting for local housing demand shocks and their correlation with housing supply elasticity partially solves the puzzles. In the third section, I provide new estimates of the elasticity of consumption with respect to housing prices. I do this first by using the Saiz elasticity as an instrument for housing prices and controlling for local demand shocks.

\subsection{Housing Prices}

The 2001-2006 housing boom was larger in cities with positive predicted demand shocks areas with large and positive Bartik shocks or less manufacturing exposure. Moreover, the effect of demand on prices was greatest in cities where the housing supply was inelastic, which allows for a rejection of the null hypothesis that housing supply elasticity alone explains why some areas had larger housing booms and busts than others. Regional demand shocks and their interaction with supply elasticity have greater explanatory power. 
This is consistent with the theoretical predictions developed in Section 4. Furthermore, estimates of the effect of supply elasticity on housing prices and other outcomes that do not control for demand associated with industry exposure suffer from an omitted variables bias. This is because supply elasticity is highly correlated with industry exposure, and industry exposure affects housing prices directly through its effects on housing demand.

Visual evidence for the association between available land and manufacturing exposure is shown in Figure 2. Table 6 formally confirms the strength of this relationship using several supply elasticity measures and industry exposure, including the manufacturing exposure measure, the Bartik shock, and import competition as measured by Acemoglu et al. (2014). These estimates consistently show that areas with more available land those that are easier to build in - had great ex ante exposure to the manufacturing sector than areas that are harder to build in. Furthermore, Table A3 shows that an association between housing supply elasticity and manufacturing exposure even holds within-states across-CBSAs, pointing to a strong fundamental (as opposed to merely regional) link between land availability and industry location. A natural explanation for this link is that factories require space, and therefore areas with lots of unavailable land have more of them.

Table A1 shows estimates of the effect of industry exposure on local payrolls. Their strong correlation with regional payrolls bolsters the argument that they are an omitted variable that directly affects housing demand, as payrolls are the mediating variable that affects housing prices in the framework introduced in the previous section. This association is not surprising; as discussed by Autor et al. (2013) (and many other papers), greater exposure to the manufacturing sector is associated with negative labor market outcomes in the early 2000s. Columns 1 and 3 show this for the boom and bust period respectively. Columns 2 and 4 quantify the effect of the Bartik shock on regional payrolls. As expected, the signs are positive and statistically significant for the Bartik shock. Furthermore, because the same industries continued to grow from 2001-2006 as from 2006-2011, the sign 
of both shocks during both the boom and the bust.

Visual evidence in 3 shows a strong negative relationship between house price growth and ex ante manufacturing share. CBSAs with more manufacturing workers had lower house price growth. The evidence in the figure suggests a somewhat nonlinear effect, whereby manufacturing concentration is less informative for areas with the greatest house price growth. Table A2 in the Appendix uses the change in exposure to Chinese imports as a regional demand shock, a measure created in Acemoglu et al. (2014). Although the estimates in this table are noisier than those using industry shares, the signs and directions are consistent with demand shocks.

A prediction of the empirical framework is that the interaction between housing elasticity (or available land) and demand shocks should matter for housing prices. Tables 5 and 7 show regression estimates from specifications of the following form:

$$
\Delta Y_{i}=\alpha+\beta_{1} \text { Elasticity }_{i}+\beta_{2} \text { Exposure }_{i}+\beta_{3} \text { Elasticity }_{i} \times \text { Exposure }_{i}+\varepsilon_{i}
$$

where Exposure $_{i}$ is either the Bartik shock or manufacturing exposure, $Y$ is either prices or quantities, and the time period is either 2001-2006 or 2006-2011, respectively the boom and bust.

Figure 3 shows the strong negative relationship between housing prices and manufacturing share at the CBSA level. Cities with more manufacturing experienced relatively smaller housing booms than cities with more manufacturing. The relationship also appears to be somewhat nonlinear, with there being little effect on housing prices for cities with a sufficiently low fraction of the workforce in manufacturing.

Columns 1 and 2 of Table 5 show how the interaction between demand shocks and elasticity affected housing prices from 2001-2006. In line with theoretical predictions, regions with more exposure to growing industries - meaning either a higher Bartik shock or a lower manufacturing share - had the greatest growth in housing prices. However, in 
areas with more available land, the effect of growing industries on prices was dampened. ${ }^{4}$

The signs of the main effects are flipped in Columns 3 and 4 compared to Columns 1 and 2, meaning that areas with greater exposure to industries that grew from 2001-2006 had housing prices that fell in relative terms, rather than rose.

The model in Section 4 does not explain why positive income shocks from 2001-2006 should be associated with falling housing prices from 2006-2011. This result is at odds with a model in which housing demand comes only from local income shocks. Rather, it is consistent with the mean reversion that is a general feature of housing markets which predates the most recent boom-bust cycle. Glaeser and Gyourko (2006) explain mean reversion in the housing market with a model of slow-moving construction combined with mean-reverting fundamental shocks. Other authors, such as Shiller (2015), instead argue that this pattern is essentially behavioral, reflecting extrapolation by investors.

\subsection{Housing Market Puzzles}

I now show how accounting for housing demand shocks affects the empirical puzzles discussed in Section 3. Both the housing supply puzzle and the Southwest Cities puzzle are reduced, but not eliminated, after incorporating industry shares as demand shocks. This means that while industry exposure is likely an important and typically unmeasured factor affecting housing demand, it may not be the only one.

The first puzzle is that areas with an inelastic housing supply had more new construction from 2001-2011 than areas with an elastic housing supply. Table 7 jointly considers the effect of elasticity and industry exposure on construction. The main finding is that larger demand shocks led to more construction, particularly so from 2001-2006, the time period that is puzzling from the perspective of elasticity alone. Furthermore, theory predicts that the interaction between elasticity and demand shocks should be positive, i.e.,

\footnotetext{
${ }^{4} \mathrm{~A}$ similar result holds when using the composite supply elasticity measure rather than unavailable land.
} 
in areas with a more elastic housing supply, positive shocks increase housing quantities by more than in areas with a negative housing supply. Estimates on the interaction terms in Table 7 show a negative affect, however, albiet one that is never precisely estimated enough to reject a zero (or even positive interaction) at conventional levels of statistical significance. This is either because the data is simply noisy, or because there are other omitted variables which continue to affect housing demand even as they are correlated with supply elasticity. The disappearance of the large and highly significant negative effect shown in Table 3 is therefore only a partial resolution of this puzzle.

Table 8 shows that the "excessive" growth in Southwestern cities is partly explained by demand shock associated with the manufacturing sector. Controlling for demand shocks, the estimated coefficient on the Southwest cities indicator falls to about 0.19 $\log$ points from 2001-2006 and to 0.33 log points from 2006-2011 (significant at 1\%), shown in Columns 1 and 2. Additional demographic controls (Columns 3-4 reduce the estimated effect further), and controls for industry shares chosen using a doubly-robust post-LASSO procedure yields smaller results still. ${ }^{5}$ Nonetheless, the estimated coefficient on the Southwest dummy are still highly statistically significant, indicating that this puzzle is also only partially solved.

This section has explored the relationship between industry exposure, housing supply elasticity and housing prices. I have shown that the incorporation of manufacturing exposure as a demand shock partially resolves both puzzles.

\footnotetext{
${ }^{5}$ To do this, first the independent variable (prices) and the treatment variable (the Southwest) indicator are independently LASSO-regressed on the possible controls, which include all two-digit NAICS industry shares and the demographic controls. The LASSO implementation used here is the lassoregress stata package by Wilbur Townsend, which uses cross-validation to select parameters. The final OLS regression then controls for the union of the control variables selected in both LASSO procedures. The algorithm is described in further detail in Chernozhukov et al. (2015).
} 


\subsection{Consumption-House Price Elasticity Estimates}

The dramatic rise and fall in housing prices from 2001-2011 has been identified as a key reason for the equally dramatic rise and fall in household consumption. Theoretical research in this area has relied on the robust and large relationship between housing prices and consumption documented by recent empirical work for both periods of rising and falling prices. ${ }^{6}$ However, the estimated consumption-house price elasticity changes when I control for local industry exposure.

Table 9 shows estimates of following OLS equation:

$$
\Delta \log \left(C_{i}\right)=\beta \Delta \log \left(P_{i}\right)+\epsilon_{i}
$$

where $i$ indexes MSAs and time-differences are taken over 2001-2006 and 2006-2011. I follow Campbell and Cocco (2007) and Attanasio et al. (2002) in estimating the consumption response to housing prices, rather than housing wealth which Mian et al. (2013) and Kaplan et al. (2016) use. $^{7}$

The estimates show a positive correlation between housing prices and the several categories of consumption during both 2001-2006 and 2006-2011. This table uses a statelevel measure of aggregate consumption from PCE regional accounts as well as CBSA-level

\footnotetext{
${ }^{6}$ What follows is an abbreviated list of the empirical papers in this area which are most closely related to mine: Mian et al. (2013) show that regions of the U.S. where household debt/income ratios increased the most between 2002 and 2006 had the greatest declines in housing consumption between 2006 and 2009; this holds even when housing supply elasticity as an instrument for debt/income ratios. Mian and Sufi (2014a) use a similar technique to study household borrowing and spending from 2002 to 2006 . Kaplan et al. (2016) replicate the findings of Mian et al. (2013) using store-level scanner data. Dynan (2012) uses household-level data from the Panel Study of Income Dynamics to show that consumption fell most among highly-leveraged households between 2007 and 2009 even when controlling for overall changes in household wealth. Closely related to these papers is the finding of Mian and Sufi (2014b) that falling housing prices affected local regional employment in the non-tradables sector, which is closely associated with local consumption. This list neglects both relevant empirical research from before the Great Recession and studies which estimate the effects of housing prices on outcomes other than household consumption.

${ }^{7}$ Berger et al. (2015) convert the housing net worth elasticity estimated by Mian et al. (2013) to a house price elasticity by multiplying it by the mean ration of housing wealth to total wealth, $0.25-0.33$. Reversing this calculation would convert the house price elasticities estimated here to housing net worth elasticities.
} 
estimates that use retail employment as a proxy for consumption, following Guren et al. (2017), as well as non-durables consumption from Nielsen Homescan data for the years 2006-2011 only.

A larger set of estimates from NIPA state-level regional accounts data is shown in Tables 9 of the Appendix, for the years 2001-2006. Consistent with theoretical predictions, durables consumption has a greater elasticity than non-durables. ${ }^{8}$ The association between housing prices and food and beverages consumption is similar to overall nondurables consumption. $^{9}$

The OLS elasticity estimates are comparable to those found in Kaplan et al., 2016. Table 4 in Kaplan et al., 2016 shows an estimated elasticity of consumption with respect ot housing prices of $0.12-0.18$ over the 2006-2009 period, i.e. the bust; for 2006-2011, I estimate elasticities of 0.12 (for CBSA retail employment, which proxies for consumption), 0.16 (for NIPA goods less housing) and 0.19 (in Nielsen data). All of the coefficient estimates are all statistically significant at the $1 \%$ level.

Next, I follow Mian and Sufi (2011), Mian et al. (2013) and others in instrumenting for housing prices using the Saiz (2010) land availability measure. As the previous section showed, a higher housing price elasticity was associated with a smaller boom and bust. This IV procedure is a first pass towards purging local demand shocks from estimates of the consumption-house price elasticity. Controlling for industry mix or manufacturing exposure as well alleviates many of the concerns with demand shocks that are correlated with the housing supply elasticity, as shown in the previous section. The specification

\footnotetext{
${ }^{8}$ I subtract PCE housing consumption from PCE durables consumption to measure non-housing durables.

${ }^{9}$ Changes in consumption expenditures are likely driven by both increased real consumption and higher prices. Stroebel and Vavra (2014) and Kaplan et al. (2016) show rising goods prices are associated with rising housing costs and that approximately $20 \%$ of the increased expenditure is due to rising prices. Unfortunately, no regional PCE deflators exist at the state level for the time periods under consideration here, so I do not separately calculate the effects on real consumption and its price.
} 
therefore includes controls for these variables: The second state is

$$
\Delta \text { Consumption }=\beta_{1} \Delta \text { HousingPrices }+\beta_{2} \text { DemandShock }
$$

and the first stage is

$$
\Delta \text { HousingPrices }=\beta_{1} \text { SaizElasticity }+\beta_{2} \text { DemandShock }
$$

Results from specifications without any controls are shown in Table 10. Specifications using additional measures of consumption are in Tables A4 (for 2001-2006) and A5 (for 2006-2011). Consistent with previous papers, I consistently find an effect between 0.1 and 0.25 , with the larger estimates for durables and smaller estimates for non-durables. State-level estimates are more noisily measured but otherwise consistent with CBSA-level estimates.

Comparing the OLS to the 2SLS estimates, it is clear that the instrumented estimates are in many cases larger than the OLS estimates. This is true as well in, for example, Kaplan et al. (2016) and Mian et al. (2013). The reason this is surprising is that the likely direction of bias in the OLS estimates is upwards: Any unmeasured income or wealth shock would raise demand for both non-housing consumption and for housing, inducing a spurious positive correlation between housing prices and other kinds of consumption. Therefore, one would expect that a valid instrumental variables strategy should reduce the estimated association between housing prices and consumption.

This fact, combined with the positive observed elasticity between elasticity and industryexposure, motivate the addition of industry measures as control variables. Simply adding the Bartik shock as a control variable, in Table 11, reduces the estimated effect of housing prices on retail employment from 0.14 to 0.05 from 2001-2006. State-level measures of goods spending fall from 0.125 to 0.11 . Using manufacturing share as a control, and using 
LASSO to choose industry shares as controls, yields similar results (shown in Tables A6 and A7).

The effects are reversed during the bust period. Because greater industry growth is associated with greater declines in housing prices during the bust period, the sign of the omitted variables bias is reversed. Adding the Bartik shock as a control variable actually increases coefficient estimates from 2006-2011; the estimated effect on retail spending rises from 0.14 to 0.20 during this time period, and the state-level measure of goods is hardly affected.

Combining the results from both time periods, I can reject that the elasticity of retail employment with respect to housing prices is the same from 2001-2006 and 2006-2011. This asymmetry is not apparent without controls, because the direction of bias varies between time periods.

The findings in this section have two main implications for empirical research on the effects of housing prices on consumption and other economic outcomes. The first implication is that there are good reasons to believe that regional demand shocks are correlated with the elasticity of housing supply. Therefore, the empirical research should either control for relevant demand shocks - such as ex ante industry shares - or use methodologies that do not rely on regional variation alone. In this case, controlling for industry shocks decreased the estimated effect of housing prices on consumption from 2001-2006 but decreased it from 2006-2011. For other variables, the sign and magnitude of the bias may be different.

The second implication is that variation in exposure to underlying demand shocks may be important for understanding heterogeneous outcomes during the boom and bust periods. This is especially salient when studying the interaction of housing prices and individual characteristics, such as home-ownership or wealth. If variation in these other characteristics is correlated with variation in exposure to demand shocks, then it may be the demand shocks rather than housing prices that explain economic behavior. For 
example, if manufacturing workers are poorer or more likely to be renters than nonmanufacturing workers, then the effects of manufacturing decline may look like differential exposure to the housing boom, when in fact it is entirely because of differential industry exposure.

\section{Conclusion}

This paper has examined the effects of housing demand shocks on housing prices and consumption during the boom and bust. My findings indicate that demand shocks due to industry exposure explain much of the correlation between housing prices, income and consumption from the years 2001-2011.

From 2001-2006, regions with employment in high-growth industries had greater housing demand. Housing prices rose by more in these regions, and most of all in regions where the housing supply was inelastic. Controlling for local demand shocks partially solves puzzles that arose under previous work which did not control for housing demand shocks. In particular, an inelastic housing supply is associated with greater construction over this time because inelastic housing supply is associated with positive job growth. Controlling for demand shocks also increases the explained fraction of housing price variance and reduces the "excess" housing price growth that occurred in the American Southwest. Finally, controlling for demand shocks reduces the estimated elasticity of durable and non-durable consumption with respect to housing prices by about $65 \%$.

From 2006-2011, exposure to high-growth industries was associated with rising payrolls and rents but falling housing prices. This is consistent with mean reversion following the 2001-2006 boom rather than direct changes in housing demand. Controlling for demand shocks does not decrease the estimated elasticity of consumption with respect to housing prices. 


\section{References}

Acemoglu, Daron, David Dorn, Gordon H. Hanson, Brendan Price, and Autor, David, "Import competition and the Great US Employment Sag of the 2000s," Technical Report, National Bureau of Economic Research 2014.

Albouy, David, "What Are Cities Worth? Land Rents, Local Productivity, and the Total Value of Amenities," Review of Economics and Statistics, November 2015, 98 (3), 477-487.

Attanasio, Orazio, James Banks, and Sarah Tanner, "Asset Holding and Consumption Volatility," Journal of Political Economy, 2002, 110 (4), 771-792.

Autor, David H., David Dorn, and Gordon H. Hanson, "The China Syndrome: Local Labor Market Effects of Import Competition in the United States," American Economic Review, 2013, 103 (6), 2121-68.

Bartik, Timothy J., "Boon or Boondoggle? The debate over state and local economic development policies," 1991.

Berger, David, Veronica Guerrieri, Guido Lorenzoni, and Joseph Vavra, "House Prices and Consumer Spending," Working Paper 216672015.

Campbell, John Y. and Joao F. Cocco, "How do house prices affect consumption? Evidence from micro data," Journal of Monetary Economics, 2007, 54 (3), 591-621.

Chernozhukov, Victor, Christian Hansen, and Martin Spindler, "Post-selection and post-regularization inference in linear models with many controls and instruments," American Economic Review, 2015, 105 (5), 486-90.

Davidoff, Thomas, "Supply Elasticity and the Housing Cycle of the 2000s," Real Estate Economics, 2013, 41 (4), 793-813.

_ , "Supply constraints are not valid instrumental variables for home prices because they are correlated with many demand factors," 2014.

Dynan, Karen, "Is a household debt overhang holding back consumption?," Brookings Papers on Economic Activity, 2012, 2012 (1), 299-362.

Glaeser, Edward L. and Joseph Gyourko, "Housing dynamics," Technical Report, National Bureau of Economic Research 2006.

_, - , and Albert Saiz, "Housing supply and housing bubbles," Journal of Urban Economics, 2008, 64 (2), 198-217.

Guren, Adam M, Alisdair McKay, Emi Nakamura, and Jón Steinsson, "Housing Wealth Effects: The Long View," Technical Report, Working Paper, Boston University 2017. 
Harmon, Oskar R., "The income elasticity of demand for single-family owner-occupied housing: An empirical reconciliation," Journal of Urban Economics, 1988, 24 (2), 173185 .

Kaplan, Greg, Kurt Mitman, and Gianluca Violante, "Non-durable Consumption and Housing Net Worth in the Great Recession: Evidence from Easily Accessible Data," Technical Report, National Bureau of Economic Research 2016.

Leamer, Edward E., "Housing is the business cycle," in "Proceedings-Economic Policy Symposium-Jackson Hole" Federal Reserve Bank of Kansas City 2007, pp. 149-233.

Mian, Atif and Amir Sufi, "The Consequences of Mortgage Credit Expansion: Evidence from the U.s. Mortgage Default Crisis," Quarterly Journal of Economics, November 2009, 124 (4), 1449-1496.

_ and _ , "House prices, home equity-based borrowing, and the us household leverage crisis," The American Economic Review, 2011, 101 (5), 2132-2156.

_ and _ , "House price gains and US household spending from 2002 to 2006," Working Paper, National Bureau of Economic Research 2014.

- and _, "What Explains the 2007-2009 Drop in Employment?," Econometrica, November 2014, 82 (6), 2197-2223.

_, Kamalesh Rao, and Amir Sufi, "Household Balance Sheets, Consumption, and the Economic Slump," Quarterly Journal of Economics, November 2013, 128 (4), 16871726 .

Nathanson, Charles G. and Eric Zwick, "Arrested development: A theory of supplyside speculation in the housing market," Unpublished Manuscript Northwestern University and University of Chicago, 2012.

Saiz, Albert, "The Geographic Determinants of Housing Supply," The Quarterly Journal of Economics, 2010, 125 (3), 1253-1296.

Shiller, Robert J., Irrational Exuberance, Princeton University Press, 2015.

Stroebel, Johannes and Joseph Vavra, "House Prices, Local Demand, and Retail Prices," Technical Report, National Bureau of Economic Research 2014. 
Table 1: Summary Statistics

\begin{tabular}{|c|c|c|c|c|c|c|c|c|}
\hline & \multicolumn{4}{|c|}{ CBSA } & \multicolumn{4}{|c|}{ State } \\
\hline & \multicolumn{2}{|c|}{$2001-2006$} & \multicolumn{2}{|c|}{ 2006-2011 } & \multicolumn{2}{|c|}{$2001-2006$} & \multicolumn{2}{|c|}{ 2006-2011 } \\
\hline & Mean & St. Dev & Mean & St. Dev & Mean & St. Dev & Mean & St. Dev \\
\hline Bartik Shock & 1.07 & 0.03 & 1.07 & 0.03 & 1.07 & 0.02 & 1.07 & 0.02 \\
\hline Manuf. Share & 0.16 & 0.08 & 0.16 & 0.08 & 0.15 & 0.06 & 0.15 & 0.06 \\
\hline Elasticity & 2.55 & 1.44 & 2.55 & 1.44 & 2.24 & 1.03 & 2.24 & 1.03 \\
\hline House Price & 0.32 & 0.2 & -0.17 & 0.23 & 0.37 & 0.19 & -0.23 & 0.21 \\
\hline Payrolls & 0.19 & 0.1 & 0.06 & 0.08 & 0.21 & 0.07 & 0.09 & 0.07 \\
\hline Permits & 0.08 & 0.05 & 0.03 & 0.02 & 0.07 & 0.04 & 0.03 & 0.01 \\
\hline Retail Emp. & 0.06 & 0.09 & -0.07 & 0.07 & 0.06 & 0.06 & -0.07 & 0.04 \\
\hline 1-Unavail Land & 0.74 & 0.21 & 0.74 & 0.21 & 0.76 & 0.15 & 0.76 & 0.15 \\
\hline Durables & & & & & 2947 & 372 & 2844 & 421 \\
\hline Goods & & & & & 10124 & 890 & 11055 & 1060 \\
\hline Log(Durables) & & & & & 0.15 & 0.07 & -0.04 & 0.08 \\
\hline Log(Goods) & & & & & 0.21 & 0.05 & 0.09 & 0.05 \\
\hline $\log ($ Total C) & & & & & 0.24 & 0.03 & 0.11 & 0.04 \\
\hline Total C & & & & & 24897 & 3343 & 27787 & 3932 \\
\hline Count & 265 & & 265 & & 51 & & 51 & \\
\hline
\end{tabular}

Table 2: House Prices and Elasticity

\begin{tabular}{lcccc}
\hline \hline & $(1)$ & $(2)$ & $(3)$ & $(4)$ \\
& CBSA Price & CBSA Price & State Price & State Price \\
& $2001-2006$ & $2006-2011$ & $2001-2006$ & $2006-2011$ \\
\hline Avail. Land & $-0.523^{* * *}$ & $0.467^{* * *}$ & $-0.535^{* * *}$ & $0.560^{*}$ \\
& $(0.0492)$ & $(0.0613)$ & $(0.151)$ & $(0.218)$ \\
& & & & \\
Constant & $0.704^{* * *}$ & $-0.513^{* * *}$ & $0.770^{* * *}$ & $-0.656^{* * *}$ \\
& $(0.0403)$ & $(0.0498)$ & $(0.116)$ & $(0.174)$ \\
\hline $\mathrm{R}^{2}$ & 0.293 & 0.182 & 0.207 & 0.166 \\
$\mathrm{~N}$ & 265 & 265 & 48 & 48 \\
\hline \hline
\end{tabular}

Sources: Saiz (2010), FHFA.

Retail measures retail employment; Goods measure goods consumption.

${ }^{*} p<0.05,{ }^{* *} p<0.01,{ }^{* * *} p<0.001$ 
Table 3: Supply Elasticity and Housing Units

\begin{tabular}{lcccc}
\hline \hline & $(1)$ & $(2)$ & $(3)$ & $(4)$ \\
& Units & Units & Units & Units \\
& $2001-2006$ & $2001-2006$ & $2006-2011$ & $2006-2011$ \\
\hline Avail. Land & -0.0186 & & -0.00609 & \\
& $(0.0164)$ & & $(0.0116)$ & \\
Elasticity & & & & -0.00250 \\
& & $-0.00704^{* * *}$ & & $(0.00133)$ \\
Constant & & $(0.00195)$ & & \\
& $0.0949^{* * *}$ & $0.0990^{* * *}$ & $0.0424^{* * *}$ & $0.0442^{* * *}$ \\
& $(0.0133)$ & $(0.00660)$ & $(0.00933)$ & $(0.00411)$ \\
\hline $\mathrm{R}^{2}$ & 0.00561 & 0.0384 & 0.00176 & 0.0138 \\
$\mathrm{~N}$ & 263 & 263 & 265 & 265 \\
\hline \hline
\end{tabular}

Sources: Saiz (2010), HUD.

Units measured as log change in housing units.

${ }^{*} p<0.05,{ }^{* *} p<0.01,{ }^{* * *} p<0.001$ 
Table 4: Supply Elasticity and Prices in Southwest States

\begin{tabular}{lcccc}
\hline \hline & $(1)$ & $(2)$ & $(3)$ & $(4)$ \\
& Prices & Prices & Prices & Prices \\
& $2001-2006$ & $2006-2011$ & $2001-2006$ & $2006-2011$ \\
\hline Avail. Land & $-0.525^{* * *}$ & $0.469^{* * *}$ & $-0.435^{* * *}$ & $0.387^{* * *}$ \\
& $(0.0486)$ & $(0.0602)$ & $(0.0501)$ & $(0.0587)$ \\
Southwest & $0.258^{* * *}$ & $-0.341^{* * *}$ & $0.226^{* * *}$ & $-0.302^{* * *}$ \\
& $(0.0471)$ & $(0.0883)$ & $(0.0594)$ & $(0.0801)$ \\
Income/Cap & & & $-0.0000167^{* *}$ & $0.0000188^{*}$ \\
& & $(0.00000619)$ & $(0.00000814)$ \\
Med. Age & & $0.0244^{* * *}$ & $-0.0226^{* *}$ \\
& & & $(0.00572)$ & $(0.00718)$ \\
Frac Homeowner & & & $-1.158^{* * *}$ & 0.470 \\
& & & $(0.204)$ & $(0.266)$ \\
Frac Mortgager & & & $0.959^{* * *}$ & $-1.606^{* * *}$ \\
& & & $(0.256)$ & $(0.337)$ \\
Mtg Denials 96 & & & $-0.0622^{*}$ & 0.0678 \\
& & & $(0.0297)$ & $(0.0350)$ \\
Constant & & & 0.279 & $0.699^{*}$ \\
& $0.697^{* * *}$ & $-0.505^{* * *}$ & $(0.260)$ & $(0.308)$ \\
\hline $\mathrm{R}^{2}$ & $(0.0402)$ & $(0.0490)$ & 0.454 & 0.378 \\
$\mathrm{~N}$ & 0.340 & 0.246 & 264 & 264 \\
\hline \hline
\end{tabular}

Sources: Saiz (2010), FHFA.

Southwest indicator equals 1 for Nevada, New Mexico and Arizona.

${ }^{*} p<0.05,{ }^{* *} p<0.01,{ }^{* * *} p<0.001$ 
Table 5: Housing Prices, Demand Shocks, and Elasticity

\begin{tabular}{lcccc}
\hline \hline & $(1)$ & $(2)$ & $(3)$ & $(4)$ \\
& $\begin{array}{c}\text { House Prices } \\
2001-2006\end{array}$ & $\begin{array}{c}\text { House Prices } \\
2001-2006\end{array}$ & $\begin{array}{c}\text { House Prices } \\
2006-2011\end{array}$ & $\begin{array}{c}\text { House Prices } \\
2006-2011\end{array}$ \\
\hline Avail. Land & $3.564^{*}$ & & $-8.640^{* * *}$ & \\
& $(1.466)$ & & $(2.027)$ & \\
Bartik Shock & & & $-7.032^{* * *}$ & $-3.657^{* * *}$ \\
& $4.760^{* * *}$ & $4.425^{* * *}$ & $(1.471)$ & $(0.760)$ \\
Avail. Land $\times$ Bartik Shock & $(1.033)$ & $(0.546)$ & & \\
& $-3.548^{* *}$ & & $8.079^{* * *}$ & \\
Elasticity & $(1.313)$ & & $(1.816)$ & \\
& & & & $-1.107^{* * *}$ \\
Elasticity $\times$ Bartik Shock & & $0.886^{* * *}$ & & $(0.231)$ \\
& & $(0.191)$ & & $1.067^{* * *}$ \\
Constant & & $-0.853^{* * *}$ & & $(0.214)$ \\
& & $(0.176)$ & & $3.709^{* * *}$ \\
$\mathrm{R}^{2}$ & $-4.694^{* * *}$ & $-4.448^{* * *}$ & $7.412^{* * *}$ & $(0.835)$ \\
$\mathrm{N}$ & $(1.158)$ & $(0.603)$ & $(1.645)$ & 0.279 \\
\hline \hline
\end{tabular}

Sources: Saiz (2010), CBP, HUD.

${ }^{*} p<0.05,{ }^{* *} p<0.01,{ }^{* * *} p<0.001$ 
Table 6: Housing Elasticity and Industry Exposure

\begin{tabular}{lcccccc}
\hline \hline & $(1)$ & $(2)$ & $(3)$ & $(4)$ & $(5)$ & $(6)$ \\
& Avail. Land & Avail. Land & Avail. Land & Elasticity & Elasticity & Elasticity \\
& $0.639^{* * *}$ & & & $5.212^{* * *}$ & & \\
Manuf. & $(0.150)$ & & & $(1.214)$ & & \\
Bartik Shock & & $-2.002^{* * *}$ & & & $-13.34^{* * *}$ & \\
& & $(0.363)$ & & & $(2.889)$ & \\
Import Exp. & & & & & & 0.0539 \\
& & & $0.0131^{*}$ & & & $(0.0469)$ \\
Constant & $0.639^{* * *}$ & $2.961^{* * *}$ & $0.715^{* * *}$ & $1.705^{* * *}$ & $17.33^{* * *}$ & $2.438^{* * *}$ \\
& $(0.0310)$ & $(0.399)$ & $(0.0210)$ & $(0.199)$ & $(3.221)$ & $(0.143)$ \\
& 0.0562 & 0.0979 & 0.0110 & 0.0792 & 0.0919 & 0.00394 \\
$\mathrm{R}$ & 264 & 264 & 264 & 264 & 264 & 264 \\
$\mathrm{~N}$ & & & & & & \\
\hline \hline
\end{tabular}

Sources: Saiz (2010), CBP.

${ }^{*} p<0.05,{ }^{* *} p<0.01,{ }^{* * *} p<0.001$ 
Table 7: Housing Units and Elasticity, Controlling for Industry Bartik

\begin{tabular}{|c|c|c|c|c|}
\hline & $\begin{array}{c}(1) \\
\text { Units } \\
2001-2006\end{array}$ & $\begin{array}{c}(2) \\
\text { Units } \\
2001-2006\end{array}$ & $\begin{array}{c}(3) \\
\text { Units } \\
2006-2011\end{array}$ & $\begin{array}{c}(4) \\
\text { Units } \\
2006-2011\end{array}$ \\
\hline Avail. Land & $\begin{array}{c}1.082 \\
(0.569)\end{array}$ & & $\begin{array}{c}0.0737 \\
(0.377)\end{array}$ & \\
\hline Bartik Shock & $\begin{array}{l}1.304^{* *} \\
(0.442)\end{array}$ & $\begin{array}{c}0.542^{*} \\
(0.223)\end{array}$ & $\begin{array}{c}0.399 \\
(0.284)\end{array}$ & $\begin{array}{c}0.225 \\
(0.126)\end{array}$ \\
\hline Avail. Land $\times$ Bartik Shock & $\begin{array}{c}-0.958 \\
(0.510)\end{array}$ & & $\begin{array}{c}-0.0560 \\
(0.341)\end{array}$ & \\
\hline Elasticity & & $\begin{array}{c}0.00751 \\
(0.0618)\end{array}$ & & $\begin{array}{c}-0.0453 \\
(0.0353)\end{array}$ \\
\hline Elasticity $\times$ Bartik Shock & & $\begin{array}{l}-0.0101 \\
(0.0566)\end{array}$ & & $\begin{array}{c}0.0410 \\
(0.0325)\end{array}$ \\
\hline Constant & $\begin{array}{c}-1.381^{* *} \\
(0.494)\end{array}$ & $\begin{array}{l}-0.510^{*} \\
(0.247)\end{array}$ & $\begin{array}{c}-0.413 \\
(0.314)\end{array}$ & $\begin{array}{c}-0.211 \\
(0.138)\end{array}$ \\
\hline $\mathrm{R}^{2}$ & 0.139 & 0.134 & 0.132 & 0.132 \\
\hline $\mathrm{N}$ & 262 & 262 & 264 & 264 \\
\hline
\end{tabular}

Sources: Saiz (2010), CBP, HUD.

${ }^{*} p<0.05,{ }^{* *} p<0.01,{ }^{* * *} p<0.001$ 
Table 8: Prices in Southwest States and Elasticity, Controlling for Industry Shares

\begin{tabular}{lcccccc}
\hline \hline & $(1)$ & $(2)$ & $(3)$ & $(4)$ & $(5)$ & $(6)$ \\
& Prices & Prices & Prices & Prices & Prices & Prices \\
& $01-06$ & $06-11$ & $01-06$ & $06-11$ & $01-06$ & $06-11$ \\
\hline Southwest & $0.188^{* * *}$ & $-0.327^{* * *}$ & $0.166^{* *}$ & $-0.293^{* * *}$ & $0.113^{*}$ & $-0.215^{*}$ \\
& $(0.0496)$ & $(0.0895)$ & $(0.0592)$ & $(0.0793)$ & $(0.0503)$ & $(0.0886)$ \\
& & & & & & \\
Avail. Land & $-0.448^{* * *}$ & $0.467^{* * *}$ & $-0.386^{* * *}$ & $0.400^{* * *}$ & $-0.238^{* * *}$ & $0.215^{* * *}$ \\
& $(0.0508)$ & $(0.0636)$ & $(0.0520)$ & $(0.0626)$ & $(0.0473)$ & $(0.0594)$ \\
\hline Controls & Ind & Ind & Ind, Demo & Ind, Demo & LASSO & LASSO \\
$\mathrm{R}^{2}$ & 0.421 & 0.264 & 0.521 & 0.398 & 0.619 & 0.572 \\
$\mathrm{~N}$ & 264 & 264 & 264 & 264 & 264 & 258 \\
\hline \hline
\end{tabular}

Sources: Saiz (2010), FHFA, CBP, US Census Bureau.

Industry controls are Bartik shock and manufacturing share; Demographic controls from 200 Census.

LASSO-chosen controls are chosen using double-robust LASSO from industry controls and shares of 2-digit NAICS industries using doubly-robust procedure as described in the text. Southwest indicator equals 1 for Nevada, New Mexico and Arizona.

${ }^{*} p<0.05,{ }^{* *} p<0.01,{ }^{* * *} p<0.001$

Table 9: House Prices and Consumption: OLS

\begin{tabular}{lccccc}
\hline \hline & $(1)$ & $(2)$ & $(3)$ & $(4)$ & $(5)$ \\
& CBSA & CBSA & CBSA & State & State \\
& Retail & Retail & Nielsen & Goods & Goods \\
& $01-06$ & $06-11$ & $06-11$ & $01-06$ & $06-11$ \\
\hline House Prices & $0.245^{* * *}$ & $0.115^{* * *}$ & $0.193^{* * *}$ & $0.113^{* * *}$ & $0.160^{* * *}$ \\
& $(0.0211)$ & $(0.0170)$ & $(0.0476)$ & $(0.0221)$ & $(0.0285)$ \\
& & & & & \\
Constant & $-0.0204^{*}$ & $-0.0520^{* * *}$ & $0.116^{* * *}$ & $-0.0420^{* * *}$ & $0.124^{* * *}$ \\
& $(0.00822)$ & $(0.00476)$ & $(0.0166)$ & $(0.00634)$ & $(0.00933)$ \\
\hline $\mathrm{R}^{2}$ & 0.326 & 0.165 & 0.0414 & 0.411 & 0.453 \\
$\mathrm{~N}$ & 264 & 265 & 265 & 51 & 51 \\
\hline \hline
\end{tabular}

Sources: NIPA regional accounts, FHFA, CBP.

Retail measures retail employment; Goods measure goods consumption excluding housing.

${ }^{*} p<0.05,{ }^{* *} p<0.01,{ }^{* * *} p<0.001$ 
Table 10: House Prices and Consumption: Typical 2SLS

\begin{tabular}{lccccc}
\hline \hline & $(1)$ & $(2)$ & $(3)$ & $(4)$ & $(5)$ \\
& CBSA & CBSA & CBSA & State & State \\
& Retail & Retail & Nielsen & Goods & Goods \\
& $01-06$ & $06-11$ & $06-11$ & $01-06$ & $06-11$ \\
\hline House Prices & $0.141^{* *}$ & $0.137^{* * *}$ & 0.299 & 0.125 & $0.182^{* *}$ \\
& $(0.0433)$ & $(0.0406)$ & $(0.153)$ & $(0.0812)$ & $(0.0707)$ \\
& & & & & \\
Constant & 0.0122 & $-0.0484^{* * *}$ & $0.134^{* * *}$ & $0.168^{* * *}$ & $0.129^{* * *}$ \\
& $(0.0140)$ & $(0.00800)$ & $(0.0289)$ & $(0.0307)$ & $(0.0175)$ \\
\hline $\mathrm{R}^{2}$ & 0.267 & 0.159 & 0.0287 & 0.204 & 0.444 \\
$\mathrm{~N}$ & 264 & 265 & 265 & 48 & 48 \\
\hline \hline
\end{tabular}

Sources: NIPA regional accounts, Saiz (2010), FHFA, CBP.

Goods consumption categories from NIPA exclude housing.

${ }^{*} p<0.05,{ }^{* *} p<0.01,{ }^{* * *} p<0.001$

Table 11: Consumption and Elasticity, Controlling for Industry Bartik

\begin{tabular}{lccccc}
\hline \hline & $(1)$ & $(2)$ & $(3)$ & $(4)$ & $(5)$ \\
& CBSA & CBSA & CBSA & State & State \\
& Retail & Retail & Nielsen & Goods & Goods \\
& $01-06$ & $06-11$ & $06-11$ & $01-06$ & $06-11$ \\
\hline House Prices & 0.0453 & $0.197^{* * *}$ & 0.291 & 0.108 & $0.179^{* *}$ \\
& $(0.0573)$ & $(0.0473)$ & $(0.177)$ & $(0.0783)$ & $(0.0693)$ \\
& & & & & \\
Bartik Shock & $1.009^{* * *}$ & $0.481^{* * *}$ & -0.0882 & $314.2^{* * *}$ & -71.39 \\
& $(0.226)$ & $(0.144)$ & $(0.554)$ & $(66.20)$ & $(59.37)$ \\
Constant & $-1.075^{* * *}$ & $-0.571^{* * *}$ & 0.230 & 0.0457 & $0.157^{* * *}$ \\
& $(0.238)$ & $(0.155)$ & $(0.602)$ & $(0.0269)$ & $(0.0359)$ \\
\hline $\mathrm{R}^{2}$ & 0.253 & 0.150 & 0.0299 & 0.424 & 0.457 \\
$\mathrm{~N}$ & 264 & 264 & 264 & 48 & 48 \\
\hline \hline
\end{tabular}

Sources: NIPA regional accounts, Saiz (2010), FHFA, CBP, CBP.

Retail measures retail employment and Goods measure total goods

from NIPA excluding housing.

${ }^{*} p<0.05,{ }^{* *} p<0.01,{ }^{* * *} p<0.001$ 


\section{$6 \quad$ Figures}

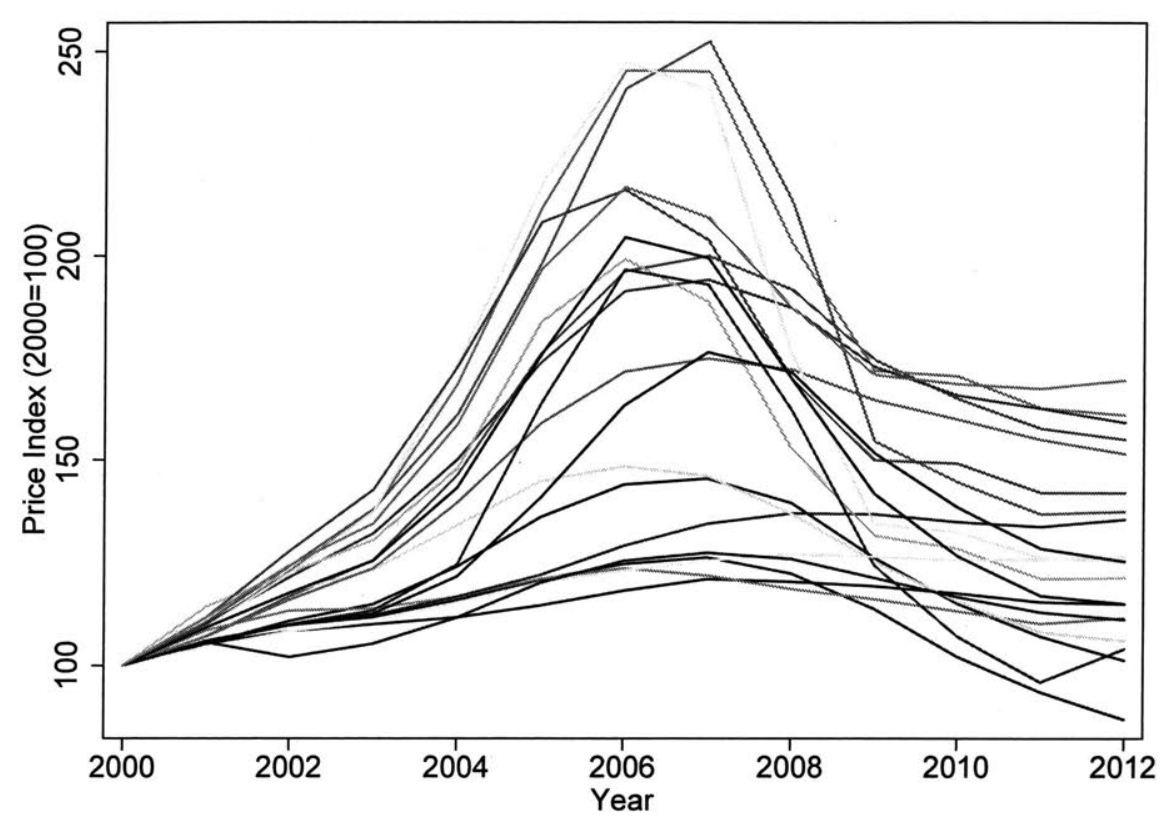

Figure 1: Housing Prices in 20 Largest CBSAs 


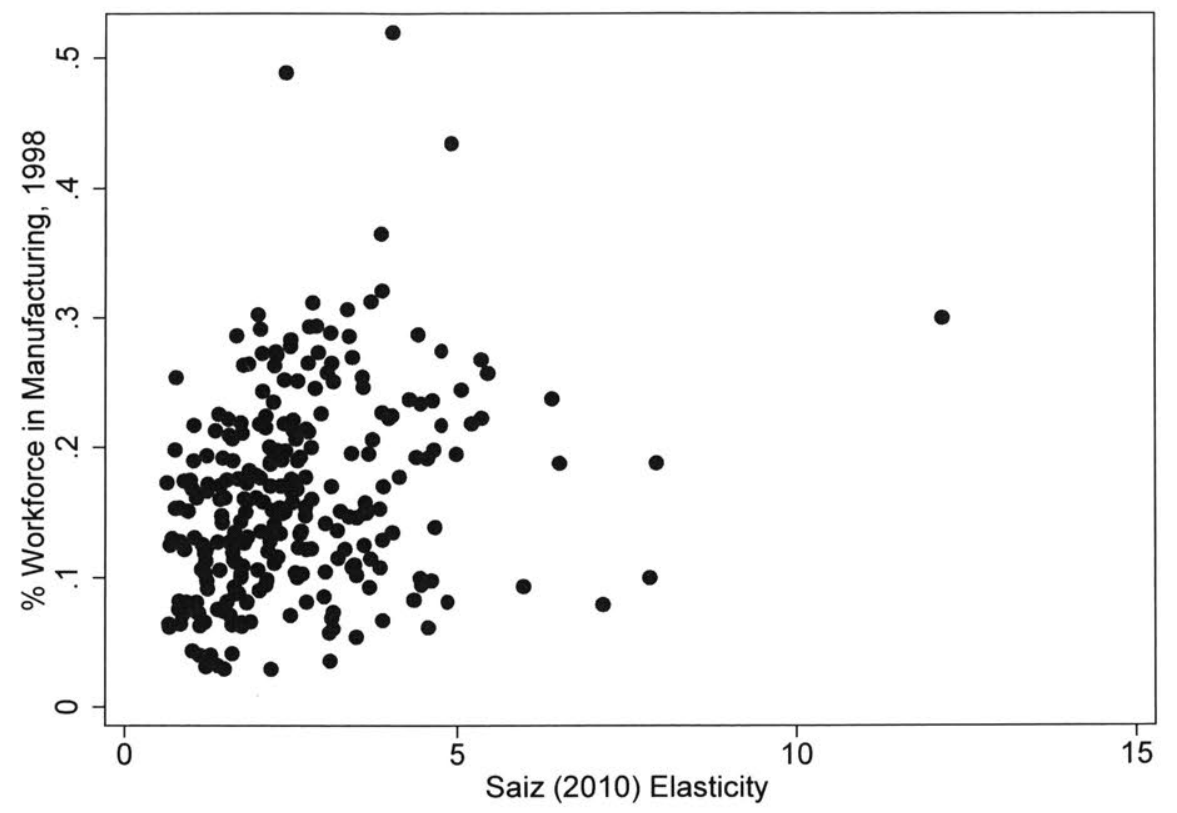

Figure 2: Elasticity vs Manufacturing Share

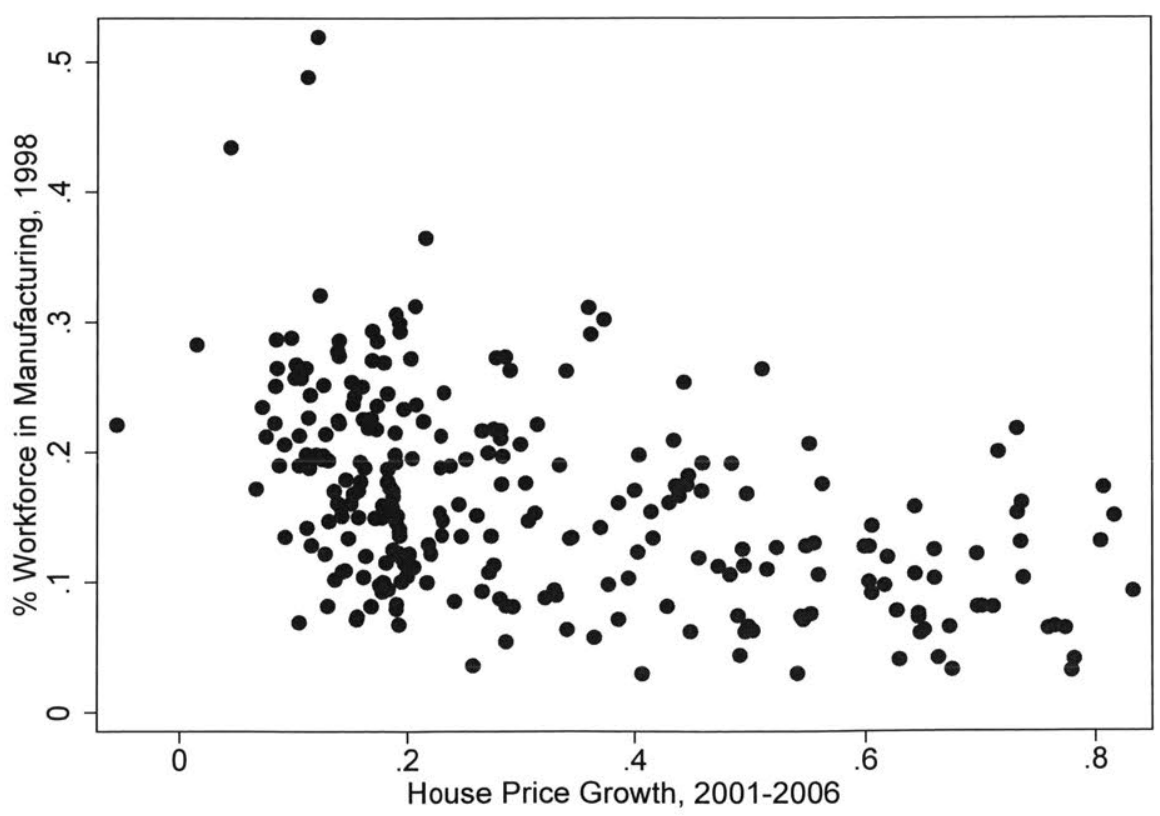

Figure 3: 2001-2006 House Price Growth and 1998 Manufacturing Employment Share 


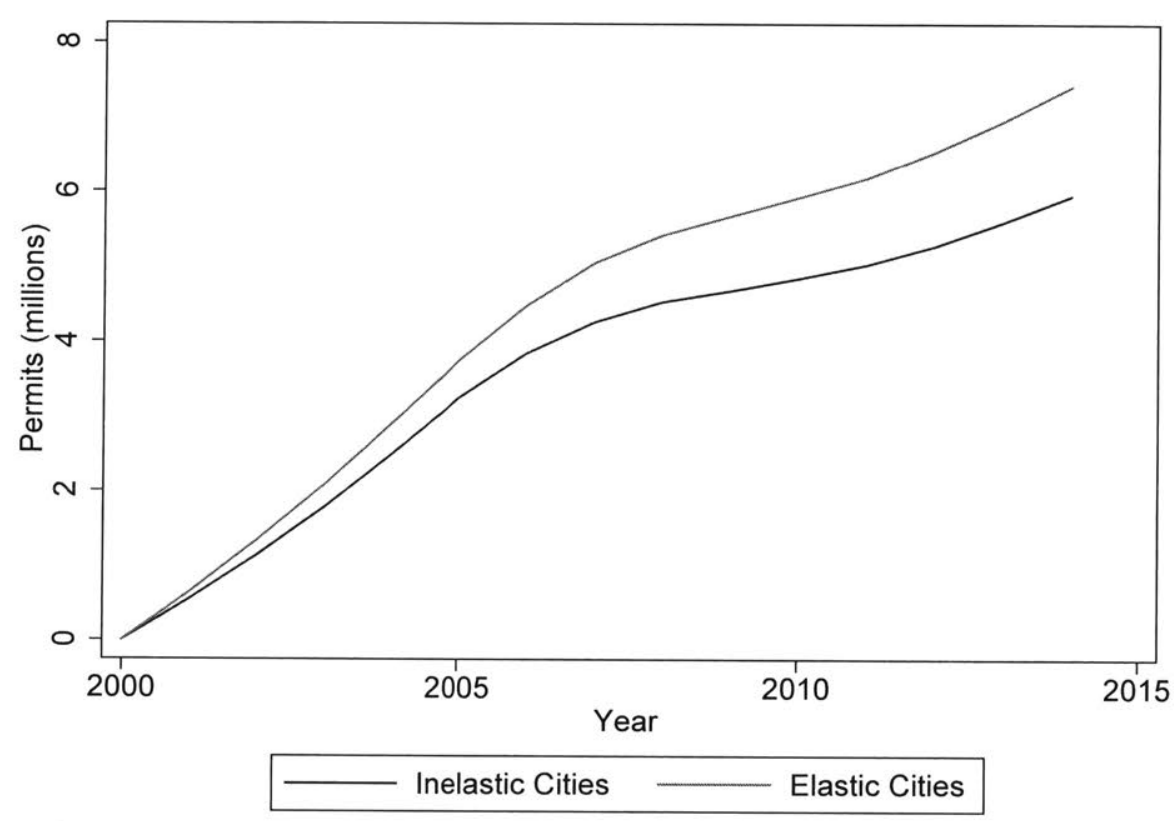

Figure 4: Total Permitting Post-2000, in Above- and Below-Median Elasticity Half of Country 


\section{A Appendix Tables}

Table A1: Payroll Growth and Industry Shares

\begin{tabular}{lcccc}
\hline \hline & $(1)$ & $(2)$ & $(3)$ & $(4)$ \\
& Payrolls & Payrolls & Payrolls & Payrolls \\
& $2001-2006$ & $2006-2011$ & $2001-2006$ & $2006-2011$ \\
\hline Manuf. & $-0.637^{* * *}$ & & $-0.238^{* *}$ & \\
& $(0.101)$ & & $(0.0867)$ & \\
Bartik Shock & & & 0.444 \\
& & $1.476^{* * *}$ & & $(0.226)$ \\
Constant & & $(0.249)$ & & -0.431 \\
& $0.297^{* * *}$ & $-1.441^{* * *}$ & $0.100^{* * *}$ & $(0.250)$ \\
\hline $\mathrm{R}^{2}$ & $(0.0171)$ & $(0.276)$ & $(0.0151)$ & 0.0290 \\
$\mathrm{~N}$ & 0.226 & 0.215 & 0.0471 & 264 \\
\hline \hline
\end{tabular}

Sources: Saiz (2010), FHFA, County Business Patterns.

${ }^{*} p<0.05,{ }^{* *} p<0.01,{ }^{* * *} p<0.001$ 
Table A2: Housing Prices, Import Exposure, and Elasticity

\begin{tabular}{lcccc}
\hline \hline & $\begin{array}{c}(1) \\
\text { House Prices } \\
2001-2006\end{array}$ & $\begin{array}{c}\text { House Prices } \\
2001-2006\end{array}$ & $\begin{array}{c}\text { House Prices } \\
2006-2011\end{array}$ & $\begin{array}{c}(4) \\
\text { House Prices } \\
2006-2011\end{array}$ \\
\hline Avail. Land & $-0.531^{* * *}$ & & $0.509^{* * *}$ & \\
& $(0.0935)$ & & $(0.129)$ & \\
Import Exp. & & & & \\
& -0.0401 & $-0.0533^{* *}$ & 0.0519 & $0.0589^{* *}$ \\
Avail. Land $\times$ Import Exp. & $(0.0356)$ & $(0.0201)$ & $(0.0480)$ & $(0.0226)$ \\
& 0.0202 & & & \\
Elasticity & $(0.0429)$ & & -0.0375 & \\
& & $-0.0848^{* * *}$ & & $0.0580)$ \\
Elasticity $\times$ Import Exp. & & $(0.0201)$ & & $(0.0220)$ \\
& & 0.00972 & & -0.0127 \\
Constant & & $(0.00626)$ & & $(0.00687)$ \\
& & & & \\
& & & & \\
$\mathrm{R}^{2}$ & $0.761^{* * *}$ & $0.590^{* * *}$ & $-0.594^{* * *}$ & $-0.464^{* * *}$ \\
$\mathrm{~N}$ & $(0.0750)$ & $(0.0553)$ & $(0.103)$ & $(0.0642)$ \\
\hline \hline
\end{tabular}

Sources: Saiz (2010), CBP, HUD, Acemoglu et al (2016).

Import exposure measures change in exposure to Chinese imports from 1991-2011.

${ }^{*} p<0.05,{ }^{* *} p<0.01,{ }^{* * *} p<0.001$

Table A3: Housing Elasticity and Industry Shares, with State FEs

\begin{tabular}{lcccc}
\hline \hline & $(1)$ & $(2)$ & $(3)$ & $(4)$ \\
& Avail. Land & Avail. Land & Elasticity & Elasticity \\
\hline Manuf. & $0.348^{*}$ & & $4.289^{* * *}$ & \\
& $(0.148)$ & & $(1.117)$ & \\
Bartik Shock & & & & $-10.42^{* * *}$ \\
& & $-1.390^{* * *}$ & & $(2.791)$ \\
Constant & & $(0.402)$ & & $14.10^{* * *}$ \\
& $0.686^{* * *}$ & $2.282^{* * *}$ & $1.855^{* * *}$ & $(3.097)$ \\
\hline State FE & $(0.0279)$ & $(0.443)$ & $(0.188)$ & Yes \\
$\mathrm{R}^{2}$ & Yes & Yes & Yes & 0.548 \\
$\mathrm{~N}$ & 0.511 & 0.527 & 0.549 & 264 \\
\hline \hline
\end{tabular}

Sources: Saiz (2010) FHFA, CBP.

${ }^{*} p<0.05,{ }^{* *} p<0.01,{ }^{* * *} p<0.001$ 
Table A4: House Prices and Consumption: Other Goods, 2001-2006

\begin{tabular}{lcccccc}
\hline \hline & $(1)$ & $(2)$ & $(3)$ & $(4)$ & $(5)$ & $(6)$ \\
& Total & Goods & Durables & Nondurables & Vehicles & Food and Bev \\
\hline House Prices & $0.104^{*}$ & 0.125 & $0.241^{*}$ & 0.0749 & $0.397^{* *}$ & 0.0920 \\
& $(0.0505)$ & $(0.0812)$ & $(0.117)$ & $(0.0713)$ & $(0.144)$ & $(0.0670)$ \\
Constant & $0.197^{* * *}$ & $0.168^{* * *}$ & 0.0608 & $0.213^{* * *}$ & $-0.156^{* *}$ & $0.141^{* * *}$ \\
& $(0.0192)$ & $(0.0307)$ & $(0.0417)$ & $(0.0280)$ & $(0.0507)$ & $(0.0252)$ \\
\hline $\mathrm{R}^{2}$ & 0.340 & 0.204 & 0.369 & 0.0968 & 0.377 & 0.205 \\
$\mathrm{~N}$ & 48 & 48 & 48 & 48 & 48 & 48 \\
\hline \hline
\end{tabular}

Sources: NIPA regional accounts, Saiz (2010), FHFA.

Goods consumption categories from NIPA exclude housing.

${ }^{*} p<0.05,{ }^{* *} p<0.01,{ }^{* * *} p<0.001$

Table A5: House Prices and Consumption: Other Goods, 2006-2011

\begin{tabular}{lcccccc}
\hline \hline & $(1)$ & $(2)$ & $(3)$ & $(4)$ & $(5)$ & $(6)$ \\
& Total & Goods & Durables & Nondurables & Vehicles & Food and Bev \\
\hline House Prices & $0.163^{* *}$ & $0.182^{* *}$ & $0.298^{* *}$ & $0.130^{*}$ & $0.553^{* * *}$ & 0.137 \\
& $(0.0606)$ & $(0.0707)$ & $(0.102)$ & $(0.0644)$ & $(0.135)$ & $(0.0710)$ \\
Constant & $0.146^{* * *}$ & $0.129^{* * *}$ & 0.0315 & $0.163^{* * *}$ & 0.0322 & $0.162^{* * *}$ \\
& $(0.0145)$ & $(0.0175)$ & $(0.0254)$ & $(0.0163)$ & $(0.0353)$ & $(0.0161)$ \\
\hline $\mathrm{R}^{2}$ & 0.537 & 0.444 & 0.448 & 0.329 & 0.463 & 0.316 \\
$\mathrm{~N}$ & 48 & 48 & 48 & 48 & 48 & 48 \\
\hline \hline
\end{tabular}

Sources: NIPA regional accounts, Saiz (2010), FHFA.

Goods consumption categories from NIPA exclude housing.

${ }^{*} p<0.05,{ }^{* *} p<0.01,{ }^{* * *} p<0.001$ 
Table A6: Consumption and Elasticity, Controlling for Manufacturing Share

\begin{tabular}{lccccc}
\hline \hline & $(1)$ & $(2)$ & $(3)$ & $(4)$ & $(5)$ \\
& CBSA & CBSA & CBSA & State & State \\
& Retail & Retail & Nielsen & Goods & Goods \\
& $01-06$ & $06-11$ & $06-11$ & $01-06$ & $06-11$ \\
\hline House Prices & 0.0736 & $0.183^{* * *}$ & 0.305 & 0.113 & $0.172^{*}$ \\
& $(0.0527)$ & $(0.0452)$ & $(0.174)$ & $(0.0948)$ & $(0.0776)$ \\
Manuf & & & & & \\
& $-0.394^{* * *}$ & $-0.196^{* * *}$ & -0.0235 & -0.140 & 0.137 \\
& $(0.0782)$ & $(0.0534)$ & $(0.241)$ & $(0.238)$ & $(0.160)$ \\
Constant & $0.0975^{* * *}$ & -0.00917 & $0.138^{*}$ & $0.193^{* *}$ & $0.105^{* *}$ \\
& $(0.0272)$ & $(0.0148)$ & $(0.0593)$ & $(0.0700)$ & $0.0389)$ \\
\hline $\mathrm{R}^{2}$ & 0.291 & 0.171 & 0.0265 & 0.231 & 0.473 \\
$\mathrm{~N}$ & 264 & 264 & 264 & 48 & 48 \\
\hline \hline
\end{tabular}

Sources: NIPA regional accounts, Saiz (2010), FHFA, CBP, CBP, US Census Bureau.

Retail measures retail employment and Goods measure total goods form NIPA excluding housing.

${ }^{*} p<0.05,{ }^{* *} p<0.01,{ }^{* * *} p<0.001$

Table A7: Consumption and Elasticity, Controlling for Post-LASSO Industry Shares

\begin{tabular}{lccccc}
\hline \hline & $(1)$ & $(2)$ & $(3)$ & $(4)$ & $(5)$ \\
& CBSA & CBSA & CBSA & State & State \\
& Retail & Retail & Nielsen & Goods & Goods \\
& $01-06$ & $06-11$ & $06-11$ & $01-06$ & $06-11$ \\
\hline House Prices & 0.0526 & $0.291^{*}$ & 0.542 & 0.0790 & 0.152 \\
& $(0.107)$ & $(0.144)$ & $(0.511)$ & $(0.0734)$ & $(0.101)$ \\
\hline LASSO Ctrl & Yes & Yes & Yes & Yes & Yes \\
$\mathrm{R}^{2}$ & 0.429 & 0.161 & 0.0744 & 0.766 & 0.678 \\
$\mathrm{~N}$ & 261 & 261 & 261 & 48 & 48 \\
\hline \hline
\end{tabular}

Sources: NIPA regional accounts, Saiz (2010), FHFA, CBP, CBP, US Census Bureau.

LASSO-Chosen controls are chosen from industry shares and demographics using doubly-robust post-LASSO as described in the text.

${ }^{*} p<0.05,{ }^{* *} p<0.01,{ }^{* * *} p<0.001$ 